\title{
Lessons Learned from Traditional Vietnam Northern Lowland Habitation
}

\author{
Hoang Manh Nguyen \\ Hanoi Architectural University (HAU), Hanoi, Vietnam \\ hmnguyen68@gmail.com
}

\begin{abstract}
This paper presents the cultural behavior to Nature of traditional housing in Vietnam Northern low land area and the discussion around the following issues:

Characteristic of climate in Vietnam Northern lowland area.

- Approaches to environmental sustainability and climate adaptation through the analysis of traditional housing in Vietnam Northern lowland area.

- Status and architectural trends of rural housing development in Northern lowland area today.
\end{abstract}

Keywords: Cultural behavior; climate adaption; Vietnam Northern lowland area; environmental sustainability

eISSN 2514-751X @ C 2018. The Authors. Published for AMER ABRA cE-Bs by e-International Publishing House, Ltd., UK. This is an open-access article under the CC BY-NC-ND license (http://creativecommons.org/licenses/bync-nd/4.0/). Peer-review under responsibility of AMER (Association of Malaysian Environment-Behaviour Researchers), ABRA (Association of Behavioural Researchers on Asians) and cE-Bs (Centre for EnvironmentBehaviour Studies), Faculty of Architecture, Planning \& Surveying, Universiti Teknologi MARA, Malaysia.

DOI: https://doi.org/10.21834/aje-bs.v3i9.299 


\subsection{Introduction}

Architecture is a synthesis of material culture, spiritual culture, and behavioral culture. Understanding and recognizing the distinctive elements of this culture is a critical basis to promote traditional values in a modern architecture with the means and tools of the era.

Architecture in each region gives us precious lessons of the perception, behavior and specific solutions to natural environment which formed the regional specific culture.

The traditional rural houses are characterized the representative architecture of $80 \%$ of Vietnam agricultural population. The traditional housing in Northern lowland area contains profound characteristics of folk culture through furniture disposition, decoration, function, direction, and campus. They represent the lifestyle, kinship, religious opinions, economic foundation, social structure, the characteristics of the ecological environment, the aesthetic concept, etc.

Along the evolution path, houses in the Northern rural area have learned how to respond to adverse climate conditions and put together valued lessons in climate adaptation. In times of urbanization with the challenges of global climate change, building on these valuable experiences and integrating with advanced technologies is what it takes to look to modern green rural housing models.

\subsection{Literature Review}

\subsection{Natural, cultural, social and economic conditions of the Northern lowland}

The Northern lowland is the cradle of the Hong River civilization based on paddy rice farming. The Northern lowland now encompasses 10 provinces and cities: Bac Ninh, Ha Nam, Hanoi, Hai Duong, Haiphong, Hung Yen, Nam Dinh, Thai Binh, Ninh Binh and Vinh Phuc.

\subsubsection{Natural conditions:}

The Northern lowland has both tropical and subtropical monsoon climates. The average annual temperature there is about $22.5-23.5$ Celsius. The average annual precipitation is 1400-2000 millimeters. The winter is cold, with low temperature and high humidity. The lowest temperature rarely goes below 0 Celsius in winter of the Northern lowland. In summer, the highest temperature may reach the 40 Celsius. There are heavy rains with relatively high intensity. Typhoons may directly affect coastal provinces as well.

\section{Cultural, social and economic settings}

The Northern lowland is an economic hub of special importance in Vietnam. This land has geographical and natural advantages, wide-ranging and abundant natural resources, large population, bounteous human resources and high education level.

Culture researchers compare the traditional rural house in Vietnam Northern lowland with many images. The image of boat associates with Vietnamese culture as it plays a major role in the natural conquest. The carvings of boats and oceans on Dong Son drum express the cohesion of ancient Vietnamese with this image. The roof tiles in the Vietnamese house associate with fish scales or a wavy water surface. The roof is like a boat of Vietnamese 
ancient people on the sea.

The traditional rural house in Vietnam Northern lowland is a skillful combination of architecture and decorative arts. The decorative arts on the traditional Vietnamese house have become a profound style meaning best wishes and provided an impressive aesthetic. The typical wooden sculpture feature in the traditional Vietnamese house tactfully hides conjunctive components and eases the feeling of heavy bearing structures. The motifs of the decorative arts are often herbs, flowers, and fruits, which reflect the desire of the owners. For example, the peach symbolizes longevity and the pomegranate symbolizes the flocks of children. These decorations show the Vietnamese spirit of harmony and towards nature.

\subsection{Planning and architecture of traditional rural Northern lowland housing}

The Vietnamese habitations are divided into the following scales: villages, hamlets, and curtilages (campus).

\subsubsection{Village:}

Vietnamese selects their village's location in high land areas or/and near water sources, which is favorable for farming or hunting. Boundaries of the village are normally protective and surrounded by green bamboo ramparts. In particular, a typical village usually has a public axis. It includes a village gate, a banyan tree, a well, a market, and a temple, which can be considered as the stem of a leaf. And the veins of the leaf consist of village houses that are normally owned by people in the same clan. Along the village's main street are strips of ponds and artificial lakes. In addition to breeding interest, they also serve as the surface water drainage, the landscape and the coordinator of the micro-climate environment. The types of land for setting up a traditional Vietnamese village usually include river sides, hills, lowlands, coastal areas, etc.

\subsubsection{Hamlet:}

In Vietnam, the hamlet is a traditional neighborhood of the Vietnamese ethnic group, but it is not classified in the government's administrative system. Hamlet is a collection of a group of families that live near each other and may have blood relationship with each other.

\subsubsection{Curtilage (Campus):}

The traditional house site of the Vietnamese people is usually organized with the principle of "ecological circle". In most of the traditional Vietnamese house, the main layout is (from front to back): a front garden (pond), a patio (yard), the main house and a garden.

A traditional rural house in Vietnam Northern lowland often comprises a main block, an ancillary block, a patio, a fish pond, a garden, livestock houses and toilets. There are often an odd number of house compartments. The load-carrying structure is often made of wood, with a sophisticated carved and highly artistic truss system.

The house is often wrapped inside earth or brick walls, with wood partitions separating the compartments. The middle compartment of the main block houses the altar and guest room. On both sides of the altar compartment are the sleeping quarters for the house owner and the eldest son. The next two compartments include one as the bedroom for women and 
the other as the storeroom for paddy, food and valuable properties. The main block often faces the South direction to fetch cool air, as illustrated in the saying "Marry a gentle wife, build a South-facing house". The ancillary block is often used as cooking space, accommodation for the help and shop for farming support and handicraft work.

The traditional Vietnamese rural housing has a good relationship with the surrounding landscape. As a result, the coordination between the inside and the outside is arranged to create a close and flexible environment. The Vietnamese believe that the harmony of houses, trees and the landscape is very important in life. They often try to recreate the nature in the house through a small landscape in the garden or yard.

\section{0 Methodology}

\subsection{Data Collection:}

Data collection will consist of surveys, redrawing, observations and interviews with housing owners. Initially, an observation survey to define the sites based on climatic and cultural characteristics $(n=200)$. Subsequently, a number samples will be identified to detail in the second round of data collection. $(n=80)$

Besides, some other research methods used as follow: Literature Review; Processing and Analysis of Data; Interpretation of Data...

\subsection{Results and Discussion}

\subsection{Lessons learned from tradition}

An evolution process that spans multiple centuries has brought substantive valuable lessons on climate-adaptive housing in the Northern lowland.

\subsubsection{Lesson of developing building site.}

Under circumstances of relatively high rainfall, house clusters in the Northern lowland are often positioned high and dry, and near lakes and ponds to ensure quick drainage. The land reclamation experience, preparation of building materials showed a longstanding culture in creation of habitats.

\subsubsection{Lessons of space organization}

The internal setting of the house is also considered to best respond to the climate. The front garden (pond) - patio - main block - back garden forms the typical design chain of most rural houses in the Northern lowland. The main block and wings are all single-storied, at right angles to each other and looking to the patio. This setting creates a good microclimate for the house and convenience in daily life. Both the main and ancillary blocks can take in plenty of cool air and sunshine while being protected from cold wind.

\subsubsection{Lessons about garden and plants}

The position and types of trees to be grown are also selectively considered in the order of 
"areca in front, banana in the back", and there for it can take in as much cool air as possible in Summer or the sunlight heat as well as fence off cold wind in Winter.

\subsubsection{Lessons of improving microclimate environment}

The interior space (except bedrooms for women and newlyweds) is also structured in a way to provide users with openness and flexibility as well as to help improve ventilation and control humidity and mould.

The porch is a transitional buffer space between the interior and exterior of the house that prevents flying rainwater and direct solar radiation, and it also provides a temperature and light cushion for the interior space. The entire front façade of the house is used for the door system (traditional multiple-panel door) that is designed to be tightly closed in winter or completely opened to merge with the exterior environment in hot seasons.

The roof slants on both sides with high gradient help improve drainage performance. Roofing materials come from nature (fan-palm, straw, sedge, thatch, boot-shaped roof tiles etc.), with high thickness and porosity to help improve insulation and ventilation.

\subsubsection{Lessons from structure and joining systems}

Structure and joining systems in traditional Northern lowland house are not only firm in front of strong storms but also flexible when relocation moving required

In addition to lessons learned on climate adaptation, rural houses in the Northern lowland also give us valuable experience on sustainable development.

\subsubsection{Lesson from eco- system}

Coupled with paddy rice farming, location selection and structural setting of a rural Northern lowland house are also beneficial to the improvement of the local biodiversity.

Green trees and water surfaces are linked together systematically to help moderate the microclimate and mitigate natural disadvantages such as solar heat and cold wind.

\subsubsection{Lesson from advantage of sunlight and the rain-water}

The natural water source inside a rural Northern lowland house is often put to effective and sustainable use. Apart from the open well system, rainwater is also collected and kept in domestic tanks for use in daily living. Quick surface drainage helps gather water in the lakes and ponds of the village and provides an important replenishment to the water supply for farming activities.

\subsubsection{Lessons about natural and environmentally friendly building materials}

Most of the materials used in a traditional Northern lowland house come from locally available, natural sources, and are highly environment-friendly. These materials may be recycled as they are continuously refreshed and do not leave construction wastes when expired.

The climatic conditions are the basic elements to create characteristics in lifestyle, building methods and Vietnamese architectural culture. With that awareness, perhaps the lesson of climate adaptation and sustainable development of Vietnamese traditional house 
will be one of the foundations to build Vietnamese architecture which has the sustainable culture.

\subsubsection{Housing status and trends in the rural Northern lowland}

As the country progresses further in its development path, urbanization will keep increasing. Changes created by urbanization can be seen most clearly through the facelift that rural areas are experiencing, and the most influences are felt in local culture, values, and housing design.

Houses in the rural Northern lowland are not exempted from the changing rules of development, as village architecture alters to take on a more urban touch and lose the builtin benefits of the traditional ecological setting.

Obviously, the traditional Northern lowland village and house pattern are under strong influence from the development and urbanization process, as this can be seen through various negative changes.

The village structure changes and public facilities are squatted. The sizes of the houses either shrink or the houses are split up, as water surface areas and trees keep disappearing. Village bamboo ranges, once deep-seated in the farmer's subconscious mind, take turns to vanish or only exist in a handful number.

Water bodies, lakes, and ponds, which play a vital role in drainage and keeping water for daily living and farming needs are reducing and getting contaminated over time.

Single-storied traditional houses are being replaced by more urbanized accommodations. While the survey records continued the adoption of the traditional housing style, expensive materials and carpenter's wage reduce households that can afford this type of house to a handful. Instead, a rising trend exists for single- or 2-storied, brick-walled houses. Wealthier households, on the other hand, would copy a random pattern of 2- or 3-storied villas with reinforced concrete roofs from big cities.

\subsection{Recommendations on housing design and planning in the rural Northern lowland with a view to modern, green housing architecture}

The 'new country' in the Northern lowland needs to be developed by drawing from and building on traditional experience, as well as combining traditional wisdom with advanced technologies and know-hows. Accordingly, the following solutions are proposed based on the natural, cultural and social conditions in the Northern lowland area:

The population density in the villages needs to be controlled, as rational land area and building density norms are introduced so that each house in the Northern lowland area becomes an ecologically balanced unit that contributes to the well-being of the village's overall biodiversity. The traditional garden-pond-breeding model should be promoted. Given the limited land resources, housing for new households should be located in untapped areas or low-productivity farming land to relieve the population pressure.

Green tree systems should be developed based on the traditional principle of taking in cool air and fencing off cold wind, protecting from gusts and storms and generating material sources for building and production. Existing lakes, ponds, and water bodies need to be dredged and maintained. Appropriate actions should be taken to reduce contamination of 
these water sources.

Efforts need to be stepped up to help create an awareness change among the public on the values of the traditional house. Promotion and technical assistance for preservation and rehabilitation of traditional houses are needed. Efforts building on and drawing from traditional experience should be encouraged for new developments. Use of urbanized (tubeshaped) houses should be restricted to prevent marring the landscape and causing the traditional rural image to disappear.

Rainwater gathering and use are to be promoted. Solid and liquid wastes need to be managed in combination with technical solutions (biogas, microorganism fertilizers etc.) to ensure pre-discharge treatment. In addition, exploration and use of new energies should be encouraged, including solar energy, wind energy and so on.

\subsection{Conclusion}

1. The characteristics of the traditional Vietnam Northern lowland house have created individual nuance for the traditional rural residents and survive until this day. Experiencing many ups and downs in the history, the traditional Vietnam Northern lowland house has unique and outstanding architectural features and lessons learned on its development, history and meanings have great values to the current building construction.

2. In the context of a new phase, many pressing issues are posed for the traditional Vietnam Northern lowland house and these lead to the wear and tear on the material and spiritual values. This is demonstrated by the degradation of home and living in it.

- Fast metabolism speed and scale, with the impact of the many causes that are in danger of becoming disfigured heritage and landscape.

- Fast metabolism revealed the antagonistic contradiction between conservation and development, between the old house and new life.

\section{Acknowledgement}

This research was supported and funded by Vietnam Ministry of Construction. We are thankful to our colleagues in Institute of Tropical Architecture who provided expertise that greatly assisted the research.

\section{References}

Architectural Research Institute, $(1998,1999)$. Traditional housing survey in Nam Dinh and Bac Ninh, working document.

Chu Quang Tru, (1994). Traditional housing design, Culture Publishing House.

Gourou, P.(2002), Tonkin delta farmers (translation), Youth Publishing House, Ho Chi Minh City

Hoang Mạnh Nguyen, (2011), Vernacular garden houses in Hue city facing with the challenge of contemporary life, 
Nguyen, H.M. / Asian Journal of Environment-Behaviour Studies (ajE-Bs), 3(9) Jul / Aug 2018 (p.57-64)

South East Asia Housing Forum, Korea.

Nguyen Khac Tung, (1994), Indigenous traditional house in Vietnam, Vol. 1, Vietnam Science and History Association, Hanoi.

Tropical Architecture Institute, (2010), Housing trend survey in the rural Northern lowland and upland. 